\title{
THE USE OF COLLABORATIVE WRITING TECHNIQUE TO IMPROVE STUDENTS' ABILITY IN WRITING DESCRIPTIVE TEXT
}

\author{
(1) Irwandi, (2) Lia Andriani \\ (1) Lecturer of English Department University of Muhammadiyah Mataram \\ (2) Student's of English Department University of Muhammadiyah Mataram
}

\begin{abstract}
This study was carried out to find out about the use of collaborative writing technique to improve students ability in writing descriptive text at the second grade of SMPN 1 Praya in acacemic year 2015/2016. The total number of sample were 40 students and they were divided into two groups. The first group was called experimental group consist of 20 students and the second group was called control group consist of 20 students. The data of study was collected by giving both of groups pre-test and the treatment just for experimental group which was taught by using collaborative writing technique, and then at the last session of the both groups was post-test with the same test items. After analyzing the data obtained, the researcher found that the use of collaborative writing technique has effect in writing descriptive text. It proved from the data analysis, the researcher found that the value of t-test was 6,3, while the value of t-table in df 38 were 2,024 for confidence level $0,05(90 \%)$ and 2,71 for confidence level 0,01 (99\%). It showed that the value of t-test is higher than t-table. It is mean that the use of collaborative writing technique has effect in writing descriptive text. So, the null hypothesis (Ho) was accepted because the use of collaborative writing technique has effect in writing descriptive text at the second grade of SMPN 1 Praya in Academic Year 2015- 2016.
\end{abstract}

\section{INTRODUCTION}

Writing is one of the language ability which is needed to be learnt besides other language ability such as listening, speaking and reading. Writing is important because writing is used to communicate. It is used as means of communication to convey the knowledge or information about a given subject. For example, in the newspaper, the reader often find the article, which is consisted of someone's opinion or the scientist's invention. purpose of all of that is to share information to each other. The function of writing is also can be as selfexpression. Perhaps at sometime the people kept a journal or a diary in which recorded our feelings and impression. When the people have finest moment, sweet memories, sad ending, or something that make them happy, they record them into a note or diary. Although that is not being published, but it is proves that writing is self-expression.

One of the writing activities in teaching and learning process in the classroom is writing descriptive text. There are many kinds of text writing, such 
as: descriptive, narrative, recount, report, argumentative, etc. The work of writing is presented in the form of text types, usually known as genres, which are closely

related to the purpose of each type. For especially the eighth grade, it is limited on descriptive, recount, and narrative. In writing descriptive text, the eight grade students are expected to be able to write a simple descriptive text correctly. They should be able to make sentences in the form of present tense and develop main idea into short descriptive text.

Moreover, the writer has done an observation at one school in Praya it is in SMP 1 Central Praya, most of the second year students' of SMPN 1 PRAYA in the academic year of 2014/2015 are not able to fill all those criteria in writing descirptive text based on the indicators in the previous explanation. In fact, in the syllabus of SMPN 1 PRAYA students' must be able to write descirptive text with appropriate content, good organization, correct diction, grammar, and mechanics.

In addition, the writing class before the research was also described in several conditions. The students' attitude and motivation toward writing was still low. It appeared that the students' were not active and enthusiastic to ask questions about writing to the teacher. They were shy and afraid to present their writings in front of the class. It means that they did not want their writings being read or known by other friends at the class.

Then, the students' did not pay attention to the teacher's explanation; they looked bored or sometimes made noise. When the teacher was explaining, the students' tended to do their own activities. And the last, they needed a long time to write a composition. As the result, the students' did not have any strategies about how to find ideas or explore them. Consequently, the students' could not revise their drafts because they thought that it was a final writing. In fact, the students' drafts still had numerous errors.

There are some researcher who have done a research about collaborative writing technique. The first, is Supiani (2011) in her titile reseach "Improving the Students' Ability in Writing Descriptive Texts Through Collaborative Writing Technique" and the result of the research, could be drawn into three points as follows: first, collaborative writing technique could improve the students' writing ability; second, collaborative writing technique could improve the students' behavior and motivation; thrid, collaborative writing technique could improve the class situation.

Second, is Fatimah Mulyani (2014) in her title research about "The Effect of Using Collaborative Writing Approach Toward Writing Ability on Narrative Paragraphs of the Third year Students' at State Junior High School 2 Kampar" and the conclusion are, first there is no significant difference of the students' writing ability on narrative paragraphs before being taught by using collaborative writing approach and conventional teaching. Second, there is a significant difference of the students' writing ability on narrative paragraphs after being taught by using collaborative writing approach and conventional teaching. Thrid, there is a significant effect of the students' writing ability on narrative paragraphs 
by using collaborative writing approach at the third year students' of State Junior High School 2 Kampar.

Based on the problems and phenomena above, the writer is interested to conduct a research which entitles the use of Collaborative Writing Technique to improve students' ability in writing descirptive text in second year of SMPN 1 PRAYA in academic year 2014/2015.

Based on the descriptions of the background above, the problem is: is there any effect of using collaborative writing technique in teaching descriptive texts?

\section{REVIEW OF RELATED LITERATUE}

\section{The Principle of Teaching writing}

Teaching writing is like swimming; if we learn to swim, we need water in swimming pool and a teacher to teach us how to be a professional swimmer (Brown, 2001: 334). Like swimming, writing is taught if we are a member of a part of language society and there is someone teaching us. In addition too Nunan $(1999 ; 29)$ The following are a few principles that every teacher should consider while planning a course, whether it is a writing course, or a course in which writing will play a part. These principles can (and should) be adapted to the many different learning situations.

a) Understand our students' reasons for writing

The greatest dissatisfaction with writing instruction comes when the teacher's goals do not match the student's, or when the teacher's goals do not match those of the school or institution in which the student works. It isimportant to understand both and to convey goals to students' in ways that make sense to them.

b) Provide many opportunities for students' to write

Writing almost always improves with practice. Evaluate your lesson plans: how much time is spent reading or talking about writing, and how much is spent actually writing? Since writing is in part a physical activity, it is like other physical activities - it requires practice, and lots of it.

c) Make feedback helpful and meaningful

Students' crave feedback on their writing, yet it doesn't always have the intended effect. If you write comments on students' papers, make sure they understand the vocabulary or symbols you use. Take time to discuss them in class.

d) Clarify for yourself, and for your students', how their writing will be evaluated.

Students' often feel that the evaluation of their writing is completely sub-jective. Teachers often hear, "I just don't understand what you want." One way to combat that feeling is to first develop a statement for yourself about what is valued in student writing, either in your classroom or in your institu-tion as a whole.

In addition Harmer (2004: 11) states for many years the teaching of writing focused on the written product rather than on the writing process. In other 
words, the students' attention was directed to the what rather than the how of the text construction. Product approches expected the student to only analyse texts in terms of what language they used and how they were constructed. However, we also need to concentrate on the process of writing; and in this regard, there are a number of strategies we need to consider:

a) The way we get students' to plan

Before getting students' to write we can encourage them to think about what they are going to write. By planning the content and sequence of what they will put down on paper (or type into the computer).

b) The way encourage them to draft, reflect, and revise

Students' who are unused to process writing lessons will need to be encouraged to reflect on what they have written, learning how to treat first draft as first attempts and not as finishes products. We may want to train them in using and responding to correction symbols. We may offer them revision checklists to use when looking through what they have wrritten with aview to making revisions.

c) The way we respond to our students' writing

In order for a process writing approach to work well, some teacher may need to rethink the way in which they react to their students' work. In pace of making correction to a finished version, they will need, at times, to respond to a work in progress. This may involve talking with individual students' about first, second, third, or fourth draft, while other members of the group are working on their own.

There is even more anxiety when writing is involved, especially when many teachers themselves do not feel entirely comfortable with writing in English, even if it is their native language (Richards and Renandya, 2002 : 306). It involves so many choices about where to go next, what is the best step to take, and what is the best route to the goal. Taking a wrong step in this context might not be as dire as stepping on a mine, but it can undermine our confidence and detonate our students' resistance. Steps that can lead us to safer ground both in planning writing courses and in helping teachers to plan writing courses.

1) Ascertaining Goals and Instututional Constraints

Students' in a recent ESL class of mine wrote about the times when they wrote or spoke in English. They felt worried, embarrassed, hampered by barriers, restrictions, and fears. We can see that taking direction from these students' and addressing comfort, confidence, and fluency as a goal would lead to a very different course from one that sees as its goal the production of an academic text with an introduction, three points, and a conclusion, and effective use of transition words.

2) Deciding On Theoritical Principles

Teachers first need to confront their ideological position and recognize their per-ceptions of the relationship between the type of writing they teach and the roles they are preparing students' for in academia and the wider world of work. The question of ideology and who determines what is taught is a question of power and reflects local conditions.

3) Planing Content 
There's a healthy controversy about what the content of writing classes should be, and teachers use any or all of the following: personal experience, social issues, cultural issues, literature, or the content of other subject areas.

From the points of view above, it can be concluded that the principle in teaching writing is not everyone can be an excellent writer; writing needs a long time and hard work to create words, sentences, and arrange them in a good composition or paragraph. Then, writing as communicative language is not only taught fluently but also accurately and uses contextual and authentic materials in the classroom. Furthermore, motivate the students to learn to write so that the students study writing successfully.

\section{The Implementation of Collaborative Writing Technique}

In response to the need for structured guidelines to make collaborative more effective, the researcher makes different roles of the students. One of them plays a role as a helper and the other as a writer. Specific tasks need to be done by the helper and the writer when they write collaboratively. These steps are described as follows:

Step 1 is idea generation. In this step, the students are hoped to understand important components of the descriptive text such as identification and description. The identification means the writer of the descriptive text identifies phenomenon to be described and the description means the writer of the descriptive text describes parts, qualities, and characteristics. To help the writer stimulate ideas their helper raise questions which mostly use wh-words as follows:

a. What tree/animal do you like?

b. What does it look like?

c. Where does it live? etc.

As the writers respond verbally to the questions, they jot down key words and are encouraged to add any relevant information they might want to write about. Then, the pair reviews the keywords in the notes and determines if the order or organization should be changed. This could be indicated by numbering the ideas. Alternatively, the ideas may seem to fall into obvious sections, which can be dealt with in turn. Such sections can be color-coded and the ideas belonging to them are underlined or highlighted with a marker. Pairs may also choose to draw lines linking or around related ideas, so that a "semantic map" is constructed.

In generating the students' ideas is intended to motivate and brainstorm the students to get ideas or to generate ideas for the topic. The teacher leads the helper to raise questions about descriptive texts in order to stimulate the writer ideas such as "What is your favorite animal/tree?", "What does it look like?", "Where does it live?" etc. Then, the writer takes those three questions and makes a list to answer each one. He/she then assigns the helper to review the writer's key words, to develop the ideas into paragraph, and to organize the ideas in order.

Step 2 is drafting. In this step, the teacher emphasizes that writers do not have to worry much about spelling as they write their drafts. Rather, the stress should be on allowing ideas to flow. 
This step aims to give the writer chances to begin writing a rough draft based on the discovered ideas to review from the helper. To write the drafts, the writer is advised not care much more about the language, spelling or punctuation or neatness. During the activity, the teacher goes around the class to provide assistance, guidance, and comments if they are necessary.

\section{Descriptive Text}

Knapp and Watkins (2005) define descriptive text as kind of taxt which purpose is two describe a particular person, place and thing in detail. The purpose of descriptive text is to give an account of imagined or factual events and phenomena (Hyland, 2003: 20). Descriptive text commonly used in personal descriptions, commonsense, description, technical description, informal reports, and scientific reports. Descriptive can occur as a text and it also can be a part of a text in different genre. Describing is also used extensively in many text types, such as information reports, literary descriptions, descriptive recounts and narrative about the sense of place or character (Knapp and Watkins, 2005: 98).

\section{Generic Structure in Descriptive Text}

Every text has its own structure. Generic structure of descriptive text are identification and description (Emilia 2011).

Table 01. generic structure of descriptive text

\begin{tabular}{|c|c|}
\hline \multicolumn{2}{|c|}{ Generic structure of descriptive text } \\
\hline Identifications & Descriptions \\
\hline $\begin{array}{l}\text { The first part is used to introduce } \\
\text { phenomenon of thing which will } \\
\text { be descibed or provides } \\
\text { informations about the subject } \\
\text { matter }\end{array}$ & $\begin{array}{l}\text { This second part is usually used to } \\
\text { described the parts of qualities, } \\
\text { characteristic of the subject (Knapp } \\
\text { and Watkins: 2005) } \\
\text { In this part, Emilia (2011: 27) } \\
\text { explains that the writer also write } \\
\text { some aspects, such as: } \\
\text { - Description as aspects: list and } \\
\text { elaborates the part or qualities } \\
\text { of the subject matter. } \\
\text { - Description of activities: could } \\
\text { be behaviors, functions, or } \\
\text { uses of the subject described. }\end{array}$ \\
\hline
\end{tabular}

Table 02. an example of generic structure of description text written. The title of the text is "My Favorite Singer".

\begin{tabular}{|l|c|}
\hline Identification & $\begin{array}{l}\text { My favorite singer is Bruno Mars. He is American singer. } \\
\text { His name is Peter Gene Hernandez. He usually called Bruno } \\
\text { Mars. He was born on October 8, 1985 in Honolulu Hawaii. }\end{array}$ \\
\hline Description & Bruno Mars has brown skin and brown eyes. He has \\
\hline
\end{tabular}




\begin{tabular}{|l|l|}
\hline aspect & $\begin{array}{l}\text { curly hair, thick mouth, and white teeth. He has a beautiful } \\
\text { voice. Beside he is a singer; he is a song writter, record } \\
\text { producer, model and dancer. } \\
\text { Bruno Mars became the best digital selling artist for }\end{array}$ \\
$\begin{array}{l}\text { Description } \\
\text { activities }\end{array}$ & $\begin{array}{l}2011 \text { for three singles in the top ten including first place with } \\
12,5 \text { million sales the single "just the way you are" and he } \\
\text { got many awards. }\end{array}$
\end{tabular}

\section{Linguistic Features of Descriptive Text}

Language features of escriptive text have been observed by Knapp and Watkins (2005).

a. Specific Participant (teacher, house, cat)

b. Simple present tense (I have a cat, we wears glasses, has, eats, sings, lays, swim);

c. Uses "linking verb" (is, are, has, have)

d. Detail noun phrases to give information about subject (it was a big ventilation, sweet young lady);

e. Various adjective functioning to describe, number classify (two strong legs, sharp white fang);

f. Relational verbs are used when classifying and describing appearance/qualities and part/function of phenomena. For example: is, are, has, have (My favorite thing is my handphone, because it is important for me. My mother is a beautiful women. She has a pointed nose);

g. Thinking and feeling verbs to express personal opinion about the subject (Police believes that the suspect is armed; I think it is a clever animal);

h. Action verbs are used when describing behaviors/uses, (Our new puppy bites our shoes);

i. Mental verbs are used when describing feelings and literary descriptions, (She felt unhappy. He liked dancing).

\section{METHOD}

The design of this studied non-equivalent control group design as a part of quasi experimental design. The reason why the reseacher choose the design is because there are two classes namely experimental group and control group that is equal with pre test and post test control group design where there is no randomization in taking sampling because the researcher does not have enough autority to choose the particular classes randomly as sample of reseach insteed true experimental design (Sugiono, 2013:116). The population of this reseach were the students' at the second year of SMPN 1 PRAYA in academic year $2015 / 2016$ with the total population where 65 students' with consist of two class. The researcher take Cluster Random Sampling. From 65 of the total population, the researcher take 40 students' as sample of the study, which is divided into two class. Therefore, the writer takes classes VIII8 (an experimental group) consist of 20 students' and VIII6 (a control group) consist of 20 students'. To obtain the 
data needed in the reseach, the writer applies pre-test and post-test. The researcher use an assessment rubric for writing that was adopted from (Jakob el.'s 1981). The whole kind of the above test is evaluate based on the description of FSI procedure writing rubrucs (Jakob el.'s 1981) which covers content, organization, vocabulary, grammar and mechanics.

To analyse the data, the writer processe the score with the following steps:

1. The writer calculated the means score of both experimental and control group.

2. The writer draw standard deviation score of two groups.

3. The writer tested the significance of two deviations.

4. Identifying between the results of t-test to t-table. The writer compared the result of $\mathrm{t}$-test to $\mathrm{t}$-table. If the result of $\mathrm{t}$-test $>\mathrm{t}$-table, the null hypothesis is rejected, if the result of t-test $<\mathrm{t}$-table, is receive.

\section{FINDING AND DISCUSSION}

\section{Findings}

The following tables bellow are the writing assessment from experimental group and control group.

Table 03. Writing Assessment of Pre-Test for Experimental Group

\begin{tabular}{|c|c|c|c|c|c|c|c|}
\hline \multirow[b]{2}{*}{ No } & \multirow[b]{2}{*}{ Subject } & \multicolumn{5}{|c|}{ ASPECT } & \multirow[b]{2}{*}{ Score } \\
\hline & & $\begin{array}{c}\text { Conte } \\
\text { nt }\end{array}$ & $\begin{array}{c}\text { Organ } \\
\text { izatio } \\
\text { n }\end{array}$ & $\begin{array}{l}\text { Vocab } \\
\text { ulary }\end{array}$ & $\begin{array}{c}\text { Langua } \\
\text { ge use }\end{array}$ & $\begin{array}{c}\text { Mechan } \\
\text { ics }\end{array}$ & \\
\hline 1. & Adit & 30 & 20 & 20 & 25 & 4 & 99 \\
\hline 2. & Ahma & 26 & 17 & 17 & 25 & 4 & 72 \\
\hline 3. & Iqba & 16 & 13 & 9 & 10 & 2 & 50 \\
\hline 4. & Amal & 21 & 13 & 9 & 17 & 3 & 63 \\
\hline 5. & Auli & 16 & 13 & 9 & 17 & 3 & 58 \\
\hline 6. & Grise & 21 & 17 & 17 & 17 & 4 & 89 \\
\hline 7. & Irfa & 21 & 13 & 13 & 17 & 3 & 67 \\
\hline 8. & Okta & 21 & 13 & 13 & 17 & 3 & 67 \\
\hline 9. & Vinny & 26 & 17 & 17 & 17 & 4 & 81 \\
\hline 10. & Cindy & 21 & 13 & 9 & 17 & 3 & 63 \\
\hline 11. & Dela & 21 & 13 & 9 & 17 & 3 & 63 \\
\hline 12. & Elya & 26 & 17 & 17 & 17 & 4 & 81 \\
\hline 13. & Femi & 30 & 17 & 17 & 21 & 4 & 89 \\
\hline 14. & Hasbi & 26 & 17 & 17 & 21 & 4 & 85 \\
\hline 15. & Lale & 21 & 17 & 17 & 21 & 4 & 80 \\
\hline 16. & Ahma & 21 & 13 & 9 & 17 & 3 & 63 \\
\hline 17. & Arya & 26 & 17 & 20 & 21 & 4 & 88 \\
\hline
\end{tabular}




\begin{tabular}{|c|l|c|c|c|c|c|c|}
\hline 18. & Harn & 26 & 17 & 17 & 21 & 4 & 85 \\
\hline 19. & Ikhw & 26 & 17 & 17 & 21 & 4 & 85 \\
\hline 20. & Muha & 26 & 17 & 17 & 21 & 4 & 85 \\
\hline \multicolumn{8}{|c|}{ TOTAL } \\
\hline
\end{tabular}

Table 04. Writing Assessment of Pre-test for Control Group

\begin{tabular}{|c|c|c|c|c|c|c|c|}
\hline \multirow[b]{2}{*}{ No } & \multirow[b]{2}{*}{ NAME } & \multicolumn{5}{|c|}{ ASPECT } & \multirow[b]{2}{*}{ SCORE } \\
\hline & & $\begin{array}{c}\text { Conte } \\
\text { nt }\end{array}$ & $\begin{array}{c}\text { Organ } \\
\text { izatio } \\
\text { n }\end{array}$ & $\begin{array}{l}\text { Vocab } \\
\text { ulary }\end{array}$ & $\begin{array}{l}\text { Langua } \\
\text { ge use }\end{array}$ & $\begin{array}{c}\text { Mechan } \\
\text { ics }\end{array}$ & \\
\hline 1. & Addie & 21 & 13 & 17 & 17 & 4 & 72 \\
\hline 2. & Arvia & 26 & 13 & 17 & 10 & 4 & 70 \\
\hline 3. & Auli & 26 & 17 & 17 & 17 & 4 & 81 \\
\hline 4. & Azal & 26 & 17 & 13 & 17 & 4 & 77 \\
\hline 5. & Annis & 26 & 17 & 17 & 17 & 4 & 81 \\
\hline 6. & Intan & 21 & 13 & 13 & 17 & 3 & 62 \\
\hline 7. & Lauz & 26 & 13 & 17 & 17 & 3 & 76 \\
\hline 8. & Lina & 26 & 17 & 13 & 21 & 3 & 80 \\
\hline 9. & Deny & 21 & 13 & 13 & 17 & 3 & 63 \\
\hline 10. & Dinda & 26 & 17 & 17 & 25 & 4 & 89 \\
\hline 11. & Dino & 26 & 20 & 17 & 21 & 3 & 71 \\
\hline 12. & Dwik & 26 & 17 & 17 & 21 & 3 & 84 \\
\hline 13. & Erika & 26 & 17 & 17 & 21 & 3 & 84 \\
\hline 14. & Hel & 26 & 17 & 17 & 21 & 3 & 84 \\
\hline 15. & Jess & 26 & 13 & 13 & 17 & 3 & 72 \\
\hline 16. & Juma & 16 & 13 & 9 & 10 & 2 & 50 \\
\hline 17. & Lalu & 26 & 13 & 9 & 10 & 2 & 73 \\
\hline 18. & Lisa & 21 & 13 & 13 & 17 & 3 & 62 \\
\hline 19. & Mard & 21 & 13 & 13 & 17 & 3 & 62 \\
\hline 20. & Maul & 21 & 13 & 13 & 17 & 3 & 62 \\
\hline \multicolumn{7}{|c|}{ TOTAL } & 1.544 \\
\hline
\end{tabular}

Table 05 Writing Assessment of Post-test for Experimental Group

\begin{tabular}{|c|c|c|c|c|c|c|c|}
\hline \multirow[b]{2}{*}{ No } & \multirow[b]{2}{*}{ NAME } & \multicolumn{5}{|c|}{ ASPECT } & \multirow[b]{2}{*}{ SCORE } \\
\hline & & $\begin{array}{c}\text { Conte } \\
\text { nt }\end{array}$ & $\begin{array}{c}\text { Organ } \\
\text { izatio } \\
\text { n }\end{array}$ & $\begin{array}{l}\text { Vocab } \\
\text { ulary }\end{array}$ & $\begin{array}{l}\text { Langua } \\
\text { ge use }\end{array}$ & $\begin{array}{c}\text { Mechan } \\
\text { ics }\end{array}$ & \\
\hline 1. & Adit & 30 & 20 & 20 & 25 & 4 & 99 \\
\hline 2. & Ahma & 30 & 20 & 20 & 25 & 4 & 99 \\
\hline 3. & Iqba & 26 & 17 & 17 & 17 & 3 & 80 \\
\hline 4. & Amal & 26 & 17 & 17 & 17 & 3 & 80 \\
\hline 5. & Auli & 26 & 17 & 17 & 25 & 3 & 88 \\
\hline
\end{tabular}




\begin{tabular}{|l|l|l|l|l|l|l|l|}
\hline 6. & Grise & 26 & 20 & 20 & 17 & 4 & 87 \\
\hline 7. & Irfa & 26 & 17 & 20 & 25 & 3 & 91 \\
\hline 8. & Okta & 30 & 20 & 17 & 25 & 3 & 95 \\
\hline 9. & Vinny & 26 & 17 & 20 & 25 & 3 & 91 \\
\hline 10. & Cindy & 26 & 17 & 17 & 17 & 3 & 63 \\
\hline 11. & Dela & 26 & 17 & 17 & 17 & 3 & 80 \\
\hline 12. & Elya & 30 & 20 & 17 & 25 & 4 & 96 \\
\hline 13. & Femi & 26 & 20 & 20 & 25 & 3 & 92 \\
\hline 14. & Hasbi & 26 & 17 & 20 & 25 & 3 & 91 \\
\hline 15. & Lale & 26 & 17 & 20 & 17 & 3 & 83 \\
\hline 16. & Ahma & 26 & 20 & 20 & 17 & 3 & 86 \\
\hline 17. & Arya & 30 & 20 & 20 & 17 & 4 & 91 \\
\hline 18. & Harn & 26 & 17 & 20 & 25 & 4 & 92 \\
\hline 19. & Ikhw & 30 & 20 & 20 & 25 & 4 & 99 \\
\hline 20. & Muha & 26 & 17 & 20 & 17 & 3 & 83 \\
\hline
\end{tabular}

Table 06 Writing Assessment of Post-test for Control Group

\begin{tabular}{|c|c|c|c|c|c|c|c|}
\hline \multirow[b]{2}{*}{ No } & \multirow[b]{2}{*}{ NAME } & \multicolumn{5}{|c|}{ ASPECT } & \multirow[b]{2}{*}{ SCORE } \\
\hline & & $\begin{array}{c}\text { Conte } \\
\text { nt }\end{array}$ & $\begin{array}{c}\text { Organ } \\
\text { izatio } \\
\mathbf{n}\end{array}$ & $\begin{array}{l}\text { Vocab } \\
\text { ulary }\end{array}$ & $\begin{array}{l}\text { Langua } \\
\text { ge use }\end{array}$ & $\begin{array}{c}\text { Mechan } \\
\text { ics }\end{array}$ & \\
\hline 1. & Addie & 26 & 17 & 17 & 17 & 3 & 80 \\
\hline 2. & Arvia & 26 & 20 & 17 & 21 & 4 & 88 \\
\hline 3. & Auli & 26 & 17 & 17 & 21 & 3 & 84 \\
\hline 4. & Azal & 26 & 17 & 20 & 21 & 3 & 87 \\
\hline 5. & Annis & 26 & 17 & 13 & 21 & 3 & 80 \\
\hline 6. & Intan & 21 & 17 & 17 & 21 & 2 & 78 \\
\hline 7. & Lauz & 26 & 17 & 17 & 17 & 3 & 80 \\
\hline 8. & Lina & 30 & 17 & 17 & 21 & 3 & 88 \\
\hline 9. & Deny & 26 & 17 & 17 & 17 & 3 & 80 \\
\hline 10. & Dinda & 26 & 17 & 20 & 21 & 3 & 87 \\
\hline 11. & Dino & 30 & 17 & 17 & 21 & 3 & 83 \\
\hline 12. & Dwik & 26 & 17 & 17 & 21 & 3 & 84 \\
\hline 13. & Erika & 26 & 17 & 17 & 21 & 3 & 84 \\
\hline 14. & $\mathrm{Hel}$ & 26 & 17 & 17 & 21 & 3 & 84 \\
\hline 15. & Jess & 21 & 13 & 17 & 17 & 3 & 71 \\
\hline 16. & Juma & 26 & 13 & 13 & 21 & 3 & 76 \\
\hline 17. & Lalu & 26 & 17 & 17 & 21 & 3 & 84 \\
\hline 18. & Lisa & 21 & 17 & 17 & 21 & 3 & 79 \\
\hline 19. & Mard & 21 & 17 & 17 & 21 & 3 & 79 \\
\hline 20. & Maul & 26 & 13 & 17 & 21 & 3 & 80 \\
\hline \multicolumn{7}{|c|}{ TOTAL } & 1.384 \\
\hline
\end{tabular}


After the writer found the writing assessment of the students, and than the writer presented in two different tables namely:

1. The students' score from experimental group student is classified by ' $\mathrm{X}$ ",

2. The students' score from control group student is classified by ' $Y$ '"

The following formula is to applied to gain the students' individual final score in the tables below:

Table 07 Raw Scores in Pre-test and Post-test of Experimental Group and Control group

\begin{tabular}{|l|c|c|l|c|c|}
\hline \multicolumn{3}{|c|}{ Experimental } & \multicolumn{3}{c|}{ Control } \\
\hline Subject & Pre- test & Post- test & Subject & Pre- test & Post- test \\
\hline Adit & 99 & 99 & Addie & 72 & 80 \\
\hline Ahma & 72 & 99 & Arvia & 70 & 88 \\
\hline Iqba & 50 & 80 & Auli & 81 & 84 \\
\hline Amal & 63 & 80 & Azal & 77 & 87 \\
\hline Auli & 58 & 88 & Annis & 81 & 80 \\
\hline Grise & 89 & 87 & Intan & 62 & 78 \\
\hline Irfa & 67 & 91 & Lauz & 76 & 80 \\
\hline Okta & 67 & 95 & Lina & 80 & 88 \\
\hline Vinny & 81 & 91 & Deny & 63 & 80 \\
\hline Cindy & 63 & 63 & Dinda & 89 & 87 \\
\hline Dela & 63 & 80 & Dino & 71 & 83 \\
\hline Elya & 81 & 96 & Dwik & 84 & 84 \\
\hline Femi & 89 & 92 & Erika & 84 & 84 \\
\hline Hasbi & 85 & 91 & Hel & 84 & 84 \\
\hline Lale & 80 & 83 & Jess & 72 & 71 \\
\hline Ahma & 63 & 86 & Juma & 50 & 76 \\
\hline Arya & 88 & 91 & Lalu & 73 & 84 \\
\hline Harn & 85 & 92 & Lisa & 62 & 79 \\
\hline Ikhw & 85 & 99 & Mard & 62 & 79 \\
\hline Muha & 85 & 83 & Maul & 62 & 80 \\
\hline Total & $\mathbf{1 . 5 1 3}$ & $\mathbf{1 . 7 6 6}$ & Total & $\mathbf{1 . 5 4 4}$ & $\mathbf{1 . 3 8 4}$ \\
\hline
\end{tabular}

Table above elaborates the raw scores in pre-test and post-test for both control and experimental group. It shows that the total number of pre-test and post-test raw score of experimental group is higher than control group. It was quoted from the total number of pre-test experimental group 1.513 while 1.544 for control group, the ratio is 31 for pre-test score of both groups and in post-test the total number of experimental group is 1.766 and than for control group is 1.384 so the ratio for both groups in post-test is 18 . The table above also shows that the highest score of the students reached for each test. The table bellow will explain them. 
Table 08. Computation the Mean of Experimental Group

\begin{tabular}{|c|l|c|c|c|c|}
\hline \multicolumn{2}{|c|}{$\mathbf{1}$} & $\mathbf{2}$ & $\mathbf{3}$ & $\mathbf{4}$ & $\mathbf{5}$ \\
\hline No. & Name of sample & Pre-test & Post-test & $\begin{array}{c}\text { Deviation } \\
\text { of pre-test } \\
\text { and post- } \\
\text { test (X) }\end{array}$ & $\begin{array}{c}\text { The } \\
\text { square } \\
\text { deviation } \\
\text { score (X) }\end{array}$ \\
\hline 1. & Adit & 99 & 99 & - & - \\
\hline 2. & Ahma & 72 & 99 & 27 & 729 \\
\hline 3. & Iqba & 50 & 80 & 30 & 900 \\
\hline 4. & Amal & 63 & 80 & 17 & 289 \\
\hline 5. & Auli & 58 & 88 & 30 & 900 \\
\hline 6. & Grise & 89 & 87 & 2 & 4 \\
\hline 7. & Irfa & 67 & 91 & 24 & 576 \\
\hline 8. & Okta & 67 & 95 & 28 & 784 \\
\hline 9. & Vinny & 81 & 91 & 10 & 100 \\
\hline 10. & Cindy & 63 & 63 & - & - \\
\hline 11. & Dela & 63 & 80 & 17 & 289 \\
\hline 12. & Elya & 81 & 96 & 15 & 225 \\
\hline 13. & Femi & 89 & 92 & 3 & 9 \\
\hline 14. & Hasbi & 85 & 91 & 6 & 36 \\
\hline 15. & Lale & 80 & 83 & 3 & 9 \\
\hline 16. & Ahma & 63 & 86 & 3 & 9 \\
\hline 17. & Arya & 88 & 91 & 3 & 9 \\
\hline 18. & Harn & 85 & 92 & 7 & 49 \\
\hline 19. & Ikhw & 85 & 99 & 14 & 244 \\
\hline 20. & Muha & 85 & 83 & 2 & 4 \\
\hline & Total & $\mathbf{1 . 5 1 3}$ & $\mathbf{1 . 7 6 6}$ & $\mathbf{3 2 1}$ & $\sum \mathbf{x}^{2}=\mathbf{5 . 1 9 3}$ \\
\hline
\end{tabular}

Table 09. Computation the Mean of Control Group

\begin{tabular}{|l|l|c|c|c|c|}
\hline \multicolumn{2}{|c|}{$\mathbf{1}$} & $\mathbf{2}$ & $\mathbf{3}$ & $\mathbf{4}$ & $\mathbf{5}$ \\
\hline No. & Name of sample & Pre-test & Post-test & $\begin{array}{c}\text { Seviation } \\
\text { of pre-test } \\
\text { and pre- } \\
\text { test (Y) }\end{array}$ & $\begin{array}{c}\text { The } \\
\text { square } \\
\text { deviation } \\
\text { score (Y) }\end{array}$ \\
\hline 1. & Addie & 72 & 80 & 8 & 64 \\
\hline 2. & Arvia & 70 & 88 & 18 & 324 \\
\hline 3. & Auli & 81 & 84 & 3 & 9 \\
\hline 4. & Azal & 77 & 87 & 10 & 100 \\
\hline 5. & Annis & 81 & 80 & 1 & 1 \\
\hline 6. & Intan & 62 & 78 & 16 & 256 \\
\hline 7. & Lauz & 76 & 80 & 4 & 16 \\
\hline 8. & Lina & 80 & 88 & 8 & 64 \\
\hline 9. & Deny & 63 & 80 & 17 & 289 \\
\hline
\end{tabular}




\begin{tabular}{|c|l|c|c|c|c|}
\hline 10. & Dinda & 89 & 87 & 2 & 4 \\
\hline 11. & Dino & 71 & 83 & 12 & 144 \\
\hline 12. & Dwik & 84 & 84 & - & - \\
\hline 13. & Erika & 84 & 84 & - & - \\
\hline 14. & Hel & 84 & 84 & - & - \\
\hline 15. & Jess & 72 & 71 & 1 & 1 \\
\hline 16. & Juma & 50 & 76 & 26 & 576 \\
\hline 17. & Lalu & 73 & 84 & 11 & 121 \\
\hline 18. & Lisa & 62 & 79 & 17 & 289 \\
\hline 19. & Mard & 62 & 79 & 17 & 289 \\
\hline 20. & Maul & 62 & 80 & 18 & 324 \\
\hline \multicolumn{2}{|c|}{ Total } & $\mathbf{1 . 5 4 4}$ & $\mathbf{1 . 3 8 4}$ & $\mathbf{1 8 5}$ & $\sum \mathbf{y}^{2}=\mathbf{2 8 7 1}$ \\
\hline
\end{tabular}

The table shows shows the computation of the mean score of experimental and control group which, was elaborated that the total number of pre-test and post-test raw scores of experimental and control group and then computed into mean score. The formula used in elaboration are:

1. To find the students' mean score of experimental and control group

a. To find the students' mean score of experimental group which used formula as pollows:

$$
\begin{aligned}
& \mathrm{Mx}=\frac{\mathbf{1 . 7 6 6}}{20} \\
& \mathrm{Mx}=88,3
\end{aligned}
$$

b. To find the students' mean score of control group, which used formula as pillows:

$$
\begin{aligned}
& \text { My }=\frac{1.384}{20} \\
& M y=69,2
\end{aligned}
$$

2. Identifying the standard deviation of experimental group and control group and the formula of standard deviation which used as follows:

a. Identifying the standard deviation of experimental group, which used formula as follows:

$$
\begin{aligned}
& \sum x=5.193-\frac{(321)^{2}}{20} \\
& \sum x=5.193-\frac{10.3041}{20} \\
& \sum x=5.193-5152.05 \\
& \sum x=40,95
\end{aligned}
$$

b. Identifying the standard deviation of control group, which used formula as follows:

$$
\begin{aligned}
& \sum y=2871-\frac{(185)^{2}}{20} \\
& \sum y=2871-\frac{34225}{20} \\
& \sum y=2871-1711,25 \\
& \sum y=1159,75
\end{aligned}
$$


3. The last, in identifying the testing of the significance of two variables standard deviation, which used formula as follows:

$$
\begin{aligned}
t & =\frac{88,3-69,2}{\sqrt{\frac{40,95+1159,75}{(20+20)-2}\left[\frac{1}{20}+\frac{1}{20}\right]}} \\
t & =\frac{19,1}{\sqrt{\frac{1159,75}{40-2}[0,05+0,05]}} \\
t & =\frac{19,1}{\sqrt{\frac{1159,75}{38} \times 0,1}} \\
t & =\frac{19,1}{\sqrt{30.5 \times 0,1}} \\
t & =\frac{19,1}{\sqrt{3.05}} \\
t & =\frac{19,1}{1.74} \\
t & =10,97
\end{aligned}
$$

\section{Discussion}

Based on the statistical analysis of data was obtained, the writer continued to interpret and discuss the result. The discussion was interpreted from the posttest score and value of mean of both groups. The finding in above explanation already shows that the mean score of experimental group higher than the mean score of control group, there is 88,3 for experimental group and there is 69,2 for control group, but based on statistical analysis of t-test, it is obtained that the critical value of t-test to 10,97 . This critical value higher than the indication of $t-$ table at degree of freedom $(\mathrm{df})=\mathrm{Nx}+\mathrm{Ny}-2=38$ for confidence level of 0,05 or $90 \%$ with 2,024 and for confidence level of 0,01 or $99 \%$ with 2,71 . Therefore if we compare the t-test with the t-table, we found that:

0,05 of t-test $=10,97>\mathrm{t}$-table $=2,024$

0,01 of t-test $=10,97>\mathrm{t}$-table $=2,71$

Based on the condition above, the t-critical value is significance enough. So, the writer may take conclusion that the null hypothesis (Ho) is accepted because the use of collaborative writing technique has effect in teaching writing skill and the alternative hypothesis (Ha) is rejected.

Collaborative writing technique was simple game and more fun for the students in teaching and learning process. According Harmer (2004) Collaborative writing is that generation of ideas is lively with two or more students' involved than it is when the writers work on their own. It has proved from this research, especially for students have gotten treatment by using collaborative writing technique. They had progress especially in their content, organization, vocabulary, grammer, and mechanics. So the researcher stated that the use of collaborative writing technique has effect in teaching writing skill at the second grade of SMPN 1 Praya in academic year 2015- 2016. 


\section{CONCLUSION AND SUGGESTION}

Based on explanation in chapter four. It was clear enough the use of collaborative writing technique has effect in teaching writing skill. It proved from the data analysis, the researcher found out that the value of t-test was 6,3 , while the value of t-table in df 38 were 2,024 for confidence level $0,05(90 \%)$ and 2,71 for confidence level 0,01 (99\%).

The explanation showed that the value of t-test is higher than t-table. This indicated that the effect of treatment was significant, or we can say that the use of collaborative writing technique has effect in teaching writing skill. It mean that the null hypothesis (Ho) was accepted because the use of collaborative writing technique has effect in teaching writing skill at the seond grade of SMPN 1 Praya in Academic Year 2015- 2016.

\section{REFERENCES}

Arikunto, Suharsimi. 2013. Prosedur Penelitian. Jakarta : PT. Rineka Cipta.

Brown, H. D, 2001. Teaching by Principles: An Interactive Approach to Language Pedagogy. Second Edition, San Francisco State University. --------------, 2004. Language Assessment: Principles and Classroom Practices. San Francisco: Addison Wesley Longman, Inc.

E. 2011. Pendekatan Genre-Based Approach Dalam Pengajaran Bahasa Inggris: Petunjuk Untuk Guru. Bandung : Rizqi press.

Ghaith, G. 2002. Writing. Available at: http://www.nadasisland.com/writing. Accessed on April 20, 2015.

Harmer, Jeremy. 2004. How to Teach Writing. New York: Longman Publishing.

Hughes, Arthur. 2003. Testing for Language Teacher, 2nd Edition. New York: Cambridge University Press.

Kellough, R. D. \& Kellough, N. G. 1999. Middle School Teaching: A Guide to Method and Resources. Third Edition, London: Prentice Hall International (UK) Limited, Inc.

Knapp, P., and Watkins, M. 2005. Genre, Text, Grammer; Technologies For Teaching And Assessing Writing. University of New South Wales Press Ltd.

Mulyani, Fatimah. 2014. A thesis; The Effect of Using Collaborative Writing Approach Toward Students' Writing Ability on Narrative Paragraphs at State Junior High School 2 Kampar. University of Islam Negeri Sultan Syarif Kasim Riau.

Nunan, David. 1999. Second Language Teaching Learning. Canada: Newbury House Teacher Development.

O’Malley, J. M., \& Pierce, L. V. 1996. Authentic Assessment for English Language Learners. Massachusetts: Addison Wesley Publishing, Inc.

Oshima, Alice., and Hogue, Ann. (2006). Writing Academic English: Fourth Edition. New York: Longman. 
Richards, J. C. and Renandya, W. A. 2002. Methodology in Language Teaching: An Anthology of Current Pranctise. Cambridge: Cambridge University Press.

Supiani. 2011. A thesis; Improving the Students' Ability in Writing Desriptive Text Throough Collaborative Writing Technique (A Classroom Action Research at Grade VIII A Students of SMP Negeri 1 Pelaihari, Tanah Laut Regency, South Kalimantan Province in the Academic Year of 2010/2011). University of Sebelas Maret Surakarta.

Spring, M. 2007. Collaborative Literary Creation and Control: A Socio- Historic, Technological and Legal Analysis. http://mako.cc//Collablit/writing/BenjMako-Hill-Collablit and Control/What is cw.html. Accessed on Mei 5th, 2015.

Tribble, Christropher. 1996. Writing. Oxford: Oxford University Press.

Ur, Penny. 1996. A Course on Language Teaching. Cambridge. Cambridge University Press.

White, Ron., Arndt, Valerie. 1997. Process Writing. London: Addison Wesley Longman Limited. 